\title{
Work ability index in Slovenian hospital nurses aged over fifty years
}

\author{
Tanja Žmauc ${ }^{1}$, Danica Železnik ${ }^{1,2}$, and Oto Težak ${ }^{3}$ \\ ${ }^{1}$ Alma Mater Europaea - ECM, Maribor, Slovenia \\ ${ }^{2}$ Faculty of Health and Social Sciences, Slovenj Gradec, Slovenia \\ ${ }^{3}$ Faculty of Electrical Engineering and Computer Science, University of Maribor, Slovenia
}

[Received in May 2019; Similarity Check in May 2019; Accepted in November 2019]

\begin{abstract}
Nurses with reduced work ability are highly susceptible to the deleterious effects of their working environments, and their rates of sick leave, disability, and early retirement are higher than average. The aim of this study was to evaluate work ability in 433 Slovenian hospital nurses aged over fifty years providing secondary care in thirteen hospitals across Slovenia. To do that we used a standardised instrument known as work ability index (WAI). Mean WAI was $36.98 \pm 6.46$ and median 38. WAI was not associated with age (Spearman's $\rho=-0.034, p=0.475$ ). Total WAI score strongly correlated with the $1^{\text {st }}$ item of the WAI questionnaire "current work ability" $(\rho=0.726, p<0.001)$. Higher WAI scores were also associated with academic education, full-time employment, and working in a single (morning) or three shifts. Our WAI findings in nurses over fifty call for systemic changes in the nursing environment to maintain good work ability among nurses until the retirement age and beyond.
\end{abstract}

KEY WORDS: nursing; demographic factors; WAI; workplace

The work of healthcare professionals is psychologically and physically demanding. Nursing staff are involved in stressful situations on a daily basis, and this can have longterm health implications. It should be noted that congestion in the health sector is a consequence of a lack of staff; in the context of increasing demands of work, nurses are required to operate under the pressure of time, interruption of tasks, and consequent low levels of concentration (1). Nurses over 50 years of age are more likely to face health problems than their younger colleagues, and poor health may affect their productivity and, most importantly, the quality of care provided and the safety of patients (2).

The ability to work should be considered an important characteristic of human health and well-being (3). It is also related to other aspects and attributes of the individual, such as lifestyle, aptitude, and mental and physical capacity (4). By assessing working ability, we can detect employees with difficulties in meeting the demands of the job early on, and this is particularly important in older employees, especially in this era when retirement age is being prolonged (5).

The concept of work ability was developed in the 1980s by Finland's Institute of Occupational Health (6), and today it is assessed with the Work Ability Index (WAI), a subjective instrument comprising seven self-assessment measures. The WAI questionnaire, which has been translated and applied in many countries across the world,

Corresponding author: Tanja Žmauc, Alma mater Europaea - ECM, Slovenska ulica 17, 2000 Maribor, Slovenia

E-mail:tanja.zmauc@gmail.com is also highly predictive. In fact, some $60 \%$ of employees with low WAI scores aged between 45 and 57 received a disability pension within 11 years of testing (7). In Slovenia, this instrument has been translated for non-commercial use by the University Rehabilitation Institute (8) and, until now, mostly used in companies with disabled employees (9-13).

A variety of studies have looked into associations between WAI and sick leave, disease (14-16), lifestyle (14, 17-18), physical activity/exercise (19-20), quality of life (3, 21-22), age (23-26), education (27), work-related stress (27-31), musculoskeletal disorders (32-35), work-family conflicts (35), changing employer or leaving the profession (36-38), night and shift work (22,39), fatigue (40), current work ability (41-43), menopause (44), migration (45), ethnicity (46), physical work capacity (47), psychosocial hazard (48), successful aging strategies (26, 49-51), individual factors $(4,52-54)$, work-related factors, working conditions and workload $(4,14,52,54)$, work injury (52), and job control (26).

The main purpose of our research was to determine WAI in hospital nurses over fifty years of age, since no such research has been conducted in Slovenia so far. The study was designed to answer whether WAI score correlates with/ depends on current work ability $\left(1^{\text {st }}\right.$ item of the WAI questionnaire), age, years of work, gender, full or part-time work hours, education level, marital status, and the type of shift. 


\section{PARTICIPANTS AND METHODS}

The study was conducted between April and December 2016 and included responses from secondary care nurses aged over 50 from 13 (of 21) general and specialised hospitals across Slovenia. Some hospitals that agreed to co-operate did not provide data as to the number of their nursing staff who met the inclusion criteria but agreed to facilitate the distribution of a limited number of survey questionnaires.

Questionnaires were distributed to 910 nurses, and 433 responded (47.6\% response rate). Of these, women nurses were in vast majority $(94.0 \%)$. Mean age was $53.75 \pm 2.40$ years and mean work experience $33.62 \pm 3.29$ years. Most participants $(75.3 \%)$ had a vocational or technical upper secondary education, $6.5 \%$ a higher vocational education, and $18.2 \%$ a $1^{\text {st }}$ cycle or $2^{\text {nd }}$ cycle academic education.

The participants were aware of the study aim. Their participation was voluntary and anonymous. We did not have to ask the Ethics Committee for approval, as the survey could not have a detrimental effect on the persons involved.

\section{Questionnaire}

We used the Slovenian translation (8) of the original Finnish survey method in this study. However, the German short version was considered in scoring (Table 1). The German short version lists only 14 disease groups instead of the original 51 diseases $(55,56)$. According to Thinschmidt and Seibt (57), this shortening yields results comparable to the original version and the differences between the two do not significantly affect the outcomes.

\section{Statistical analysis}

For statistical analysis we used the IBM SPSS version 22.0 (IBM Inc., Armonk, NY, USA). The WAI results are presented as arithmetic mean and standard deviation (mean \pm SD) or as median as a measure of the central tendency of the entire sample (6) and range (min-max).

Correlations between WAI and current work ability, age, and years of work were analysed with Spearman's correlation. Mann-Whitney U test was used to test differences in WAI for the independent variables of gender and work hours.

Differences in WAI for the other variables were analysed with the Kruskal-Wallis test. For post-hoc tests we used the Mann-Whitney test of differences between pairs of categories. The level of significance was set to $p<0.05$. The level of significance for post-hoc tests was set to 0.05 divided by the number of comparisons performed (Bonferroni correction).

\section{RESULTS}

Table 2 shows that the mean WAI in our nurses was $36.98 \pm 6.46$. According to categorisation (Table 3), it was "good" for most of them (41.57\%).

Table 1 Dimensions covered by the WAI, the number of questions used to evaluate each, and the scoring of the responses (WAI short version)

\begin{tabular}{|c|c|c|c|}
\hline Item & & $\begin{array}{l}\text { Number of } \\
\text { questions }\end{array}$ & Scoring of the responses \\
\hline 1 & $\begin{array}{l}\text { Current work ability compared to the best } \\
\text { work ability }\end{array}$ & 1 & $\begin{array}{l}\qquad 0-10 \text { points } \\
\text { (value circled in the questionnaire) }\end{array}$ \\
\hline 2 & Work ability in relation to demands of work & 2 & score weighted according to the nature of the work* \\
\hline 3 & $\begin{array}{c}\text { Diagnosed diseases } \\
\text { (only diseases diagnosed by a physician are } \\
\text { counted) }\end{array}$ & $\begin{array}{c}1 \\
\text { (list of } 14 \\
\text { disease } \\
\text { groups) }\end{array}$ & $\begin{array}{c}7 \text { points }=\text { no disease } \\
5 \text { points }=1 \text { disease } \\
3 \text { points }=2 \text { diseases } \\
3 \text { points }=3 \text { diseases } \\
1 \text { point }=4 \text { diseases } \\
1 \text { point }=5 \text { and more diseases }\end{array}$ \\
\hline 4 & Estimated work impairment due do diseases & 1 & $\begin{array}{l}\qquad 1-6 \text { points } \\
\text { (value circled in the questionnaire; the worst value } \\
\text { should be chosen) }\end{array}$ \\
\hline 5 & Sick leave during the past 12 months & 1 & $\begin{array}{l}\qquad 1-5 \text { points } \\
\text { (value circled in the questionnaire) }\end{array}$ \\
\hline 6 & $\begin{array}{c}\text { Own prognosis of work ability two years } \\
\text { from now }\end{array}$ & 1 & $\begin{array}{l}1,4 \text {, or } 7 \text { points } \\
\text { (value circled in the questionnaire) }\end{array}$ \\
\hline
\end{tabular}

The total number of points from the question series are added together, and the sum is modified as

Mental capacity

7 (item 7 refers to the respondent's life in general - at home and at work
3 follows:

sum 0 to $3=1$ point

sum 4 to $6=2$ points

sum 7 to $9=3$ points

sum 10 to $12=4$ points

*weighting in accordance with instructions $(6,56)$ 
Table 2 Scores of seven dimensions in the assessment of WAI

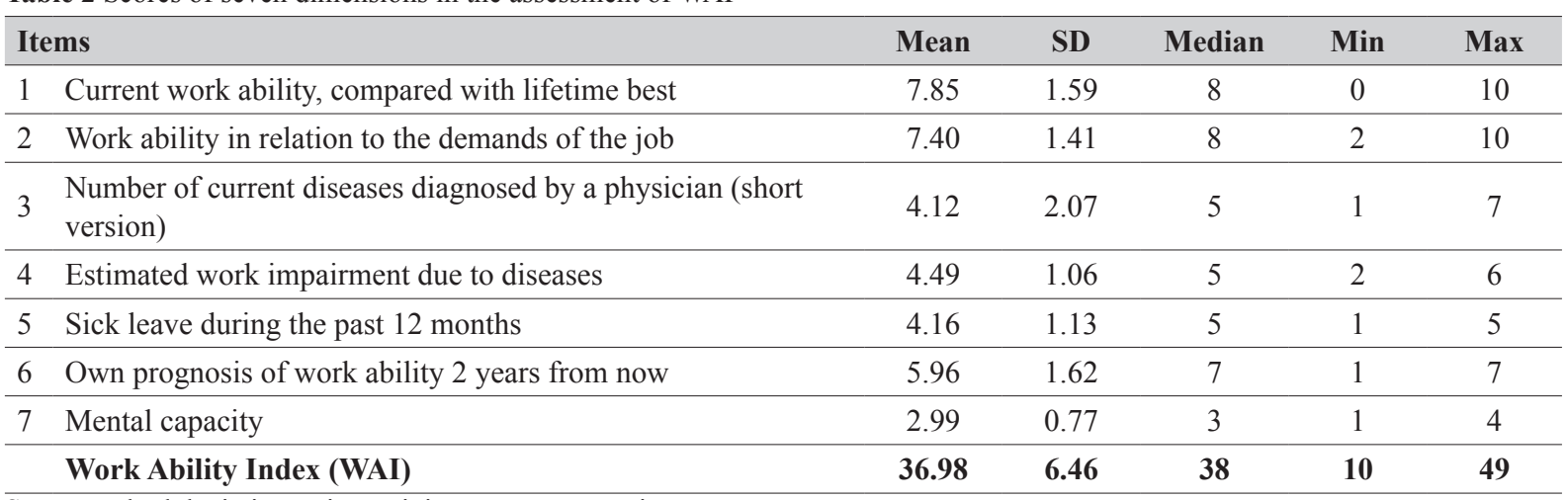

SD - standard deviation; min - minimum; max - maximum

Table 3 Categorical analysis of the WAI of nurses over fifty years of age

\begin{tabular}{lcc}
\hline Work Ability Index & $\mathbf{f}$ & $\mathbf{f} \%$ \\
\hline Poor (7-27) & 36 & 8.31 \\
\hline Moderate (28-36) & 146 & 33.72 \\
\hline Good (37-43) & 180 & 41.57 \\
\hline Excellent (44-49) & 71 & 16.40 \\
\hline Total & 433 & 100.0 \\
\hline
\end{tabular}

Spearman's correlation established a strong positive correlation between the WAI score and the self-assessment of current work ability $(\rho=0.726 ; p<0.001)$ (Figure 1$)$. However, WAI did not correlate with age $(\rho=-0.034$; $p=0.475)$ (Figure 2$)$ or years of work $(\rho=-0.090 ; p=0.061)$.

Table 4 shows the WAI analysis regarding individual demographic variables. Even though male nurses scored higher, gender differences in WAI scores were not significant $(\mathrm{U}=4296.5 ; \mathrm{p}=0.108)$. Similarly, marital status did not significantly affect WAI scores $\left(\chi^{2}=7.707\right.$; $\mathrm{df}=3$; $\mathrm{p}=0.052)$. However, education level $\operatorname{did}\left(\chi^{2}=15.370 ; \mathrm{df}=2\right.$; $\mathrm{p}<0.001)$. Table 5 shows statistically significant differences between vocational or technical upper secondary education and the $1^{\text {st }}$ or $2^{\text {nd }}$ cycle academic education $(U=9368 ; p<$ 0.001 ) and between the $1^{\text {st }}$ cycle professional education and the $1^{\text {st }}$ or $2^{\text {nd }}$ cycle academic education $(U=725 ; p=0.007)$.

As for work hours, part-time nurses had significantly lower WAI scores than the full-timers. WAI scores also significantly differed between types of shift work $\left(\chi^{2}=10.690 ; \mathrm{df}=2 ; \mathrm{p}=0.005\right)$ (see also Table 6 ). Nurses who worked in two-shift rotations had significantly lower WAI score than those working in the morning shift $(U=3959$; $p=0.012)$ or three-shift rotations $(U=7642 ; p=0.001)$.

\section{DISCUSSION AND CONCLUSION}

The mean WAI of our nurses over fifty (36.98 points, average age 53.75 years) is lower than in similar surveys $(5,21-22,25,31-32,36,39,40,44,47,52-54)$ but still bordering on "good". It should be noted that the average age of the participants in these studies was lower. However, even though many studies $(1,5,27,28,34,47,48,53)$ have observed that WAI decreases with age, we did not establish that association (Figure 2). Our study also showed no correlation between WAI score and years of work or gender.

We also established a strong correlation between the dimension of current work ability and the entire WAI. This correlation was also reported by studies on much larger samples investigating if current work ability could replace the WAI questionnaire $(26,41-43)$. In contrast, some researchers have come to the conclusion that current work ability is an insufficient measure in itself, as it poorly identifies the risk of disability retirement, and have therefore recommended that researchers should stick to the complete WAI instrument. Even so, current work ability could serve as a screening tool, before a complete WAI questionnaire is used in employees singled out by low current work ability scores (41).

Unlike some earlier studies $(27,47)$ reporting significantly higher WAI in singles than the married persons or those having a relationship, and unlike a study supporting that being married is associated with higher work ability score (58), we found no significant correlation between marital status and WAI, which is in accordance with the report by Carel et al. (5).

Some studies indicate that the WAI of nurses depends on their position and duties, which is also related to their level of education (5). According to several reports, lower education is a predictor of lower $\operatorname{WAI}(5,22,40)$. The same has been confirmed by our finding that nurses with academic degree scored significantly better than the rest.

Better WAI scores of full-time nurses can be interpreted in the light of the fact that part-time jobs are usually taken by nurses who cannot work full time for objective reasons, including poorer work ability. 


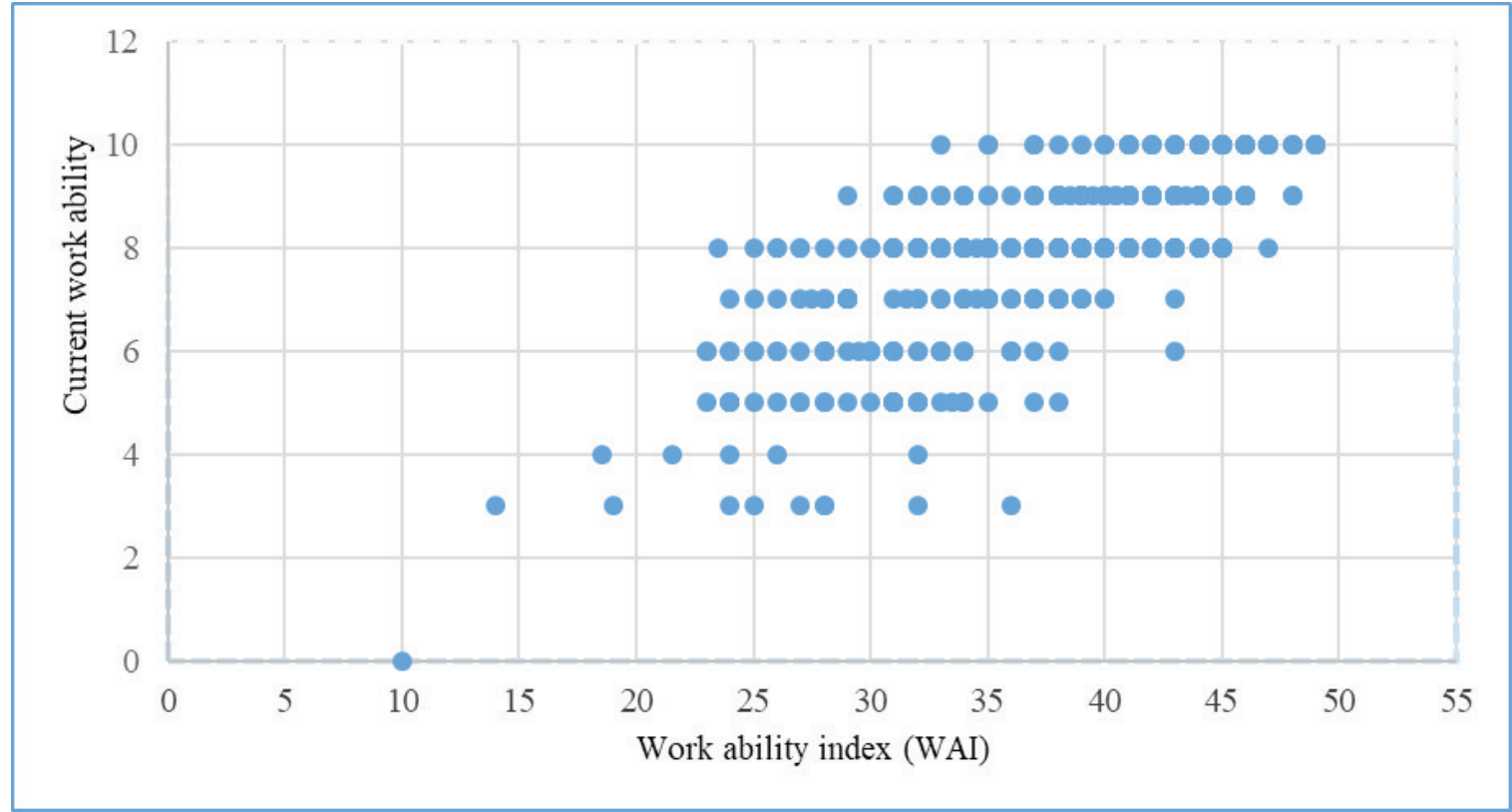

Figure 1 Relationship of the WAI and the current work ability of nurses over fifty

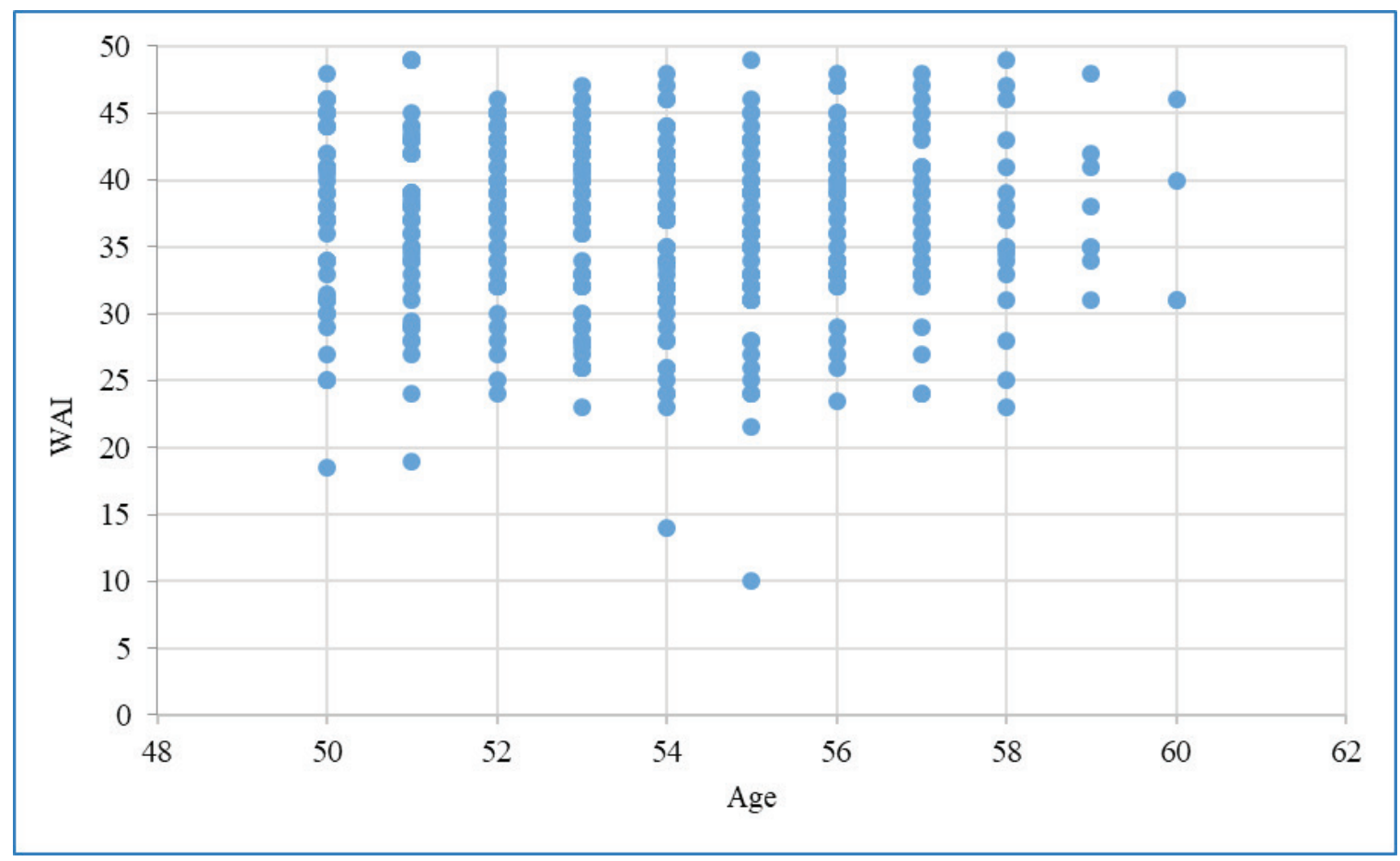

Figure 2 WAI in relation to the age (in years) of nurses over fifty

As for significantly higher WAI scores in the morning shift and three-shift nurses than in those working two shifts, our study confirms the association between shift work and work ability reported earlier (22), but it also points to a specific difference from a study reporting lowest WAI in people working all three shifts on a rotating basis (47). Namely, Slovenian nurses over 50 years of age who experience a decline in work ability can take advantage of the collective agreement for nursing employees in Slovenia
(59, article 46) and exclude themselves from three-shift work.

WAI scores reported in our study call for action to maintain and improve the work ability of nurses. It is necessary to determine whether the characteristics of the workplace and lifestyle of an employee improve or threaten the ability to work. In addition, all risks arising from the working environment, the organisation of work, and problems with superiors should be eliminated (6). 
Table 4 Descriptive statistics of WAI by socio-demographic factors and statistical differences between groups

\begin{tabular}{|c|c|c|c|c|c|c|c|}
\hline & $\mathbf{N}$ & Min & Max & Mean & SD & Median & \\
\hline \multicolumn{8}{|l|}{ Gender } \\
\hline Female & 407 & 10 & 49 & 36.83 & 6.45 & 37 & \multirow{2}{*}{$\begin{array}{c}U=4296.5 ; \\
p=0.108\end{array}$} \\
\hline Male & 26 & 27 & 49 & 38.85 & 6.50 & 41 & \\
\hline \multicolumn{8}{|l|}{ Education level } \\
\hline Vocational or technical upper secondary education & 326 & 10 & 49 & 36.46 & 6.46 & 37 & \multirow{3}{*}{$\begin{array}{c}\chi^{2}=15.370 ; \\
d f=2 ; \\
p<0.001\end{array}$} \\
\hline $\begin{array}{l}\text { Higher vocational education, } 1^{\text {st }} \text { cycle professional } \\
\text { education }\end{array}$ & 28 & 19 & 46 & 35.93 & 5.75 & 36.5 & \\
\hline $1^{\text {st }}$ or $2^{\text {nd }}$ cycle academic education & 79 & 14 & 49 & 39.31 & 6.26 & 41 & \\
\hline \multicolumn{8}{|l|}{ Marital status } \\
\hline Single & 35 & 31 & 49 & 39.91 & 4.75 & 41 & \multirow{4}{*}{$\begin{array}{c}\chi^{2}=7.707 \\
d f=3 ; \\
p=0.052\end{array}$} \\
\hline Married or cohabiting & 352 & 10 & 49 & 36.73 & 6.49 & 37 & \\
\hline Widowed & 16 & 24 & 47 & 36.88 & 6.21 & 37 & \\
\hline Divorced & 28 & 24 & 49 & 35.91 & 7.52 & 33.5 & \\
\hline \multicolumn{8}{|l|}{ Work hours } \\
\hline Full-time & 409 & 10 & 49 & 37.39 & 6.21 & 38 & \multirow{2}{*}{$\begin{array}{l}\mathrm{U}=1715 \\
\mathrm{p}<0.001\end{array}$} \\
\hline Part-time & 24 & 19 & 44 & 29.33 & 6.11 & 28.5 & \\
\hline \multicolumn{8}{|l|}{ Shift type } \\
\hline Morning shift & 106 & 14 & 48 & 37.28 & 6.89 & 38 & \multirow{3}{*}{$\begin{array}{c}\chi^{2}=10.690 ; \\
d f=2 ; \\
p=0.005\end{array}$} \\
\hline Two-shift rotation & 94 & 19 & 48 & 35.31 & 6.14 & 35.5 & \\
\hline Three-shift rotation & 211 & 10 & 49 & 37.69 & 6.19 & 38.0 & \\
\hline
\end{tabular}

$\mathrm{U}$ - test statistic of Mann-Whitney U test; $\chi^{2}$ - test statistic of Kruskal-Wallis test

Table 5 Differences in WAI by education

\begin{tabular}{llccc}
\hline Level of education & \multicolumn{1}{c}{$\begin{array}{c}\text { Mean } \\
\text { Difference }\end{array}$} & $\mathbf{U}$ & $\mathbf{p}$ \\
\hline $\begin{array}{l}\text { Vocational or technical upper } \\
\text { secondary education }\end{array}$ & $\begin{array}{l}\text { Higher vocational education, first cycle } \\
\text { professional education }\end{array}$ & 0.53 & 4254 & 0.550 \\
\cline { 2 - 5 } & First or second cycle academic education & -2.85 & 9368 & 0.000 \\
\hline $\begin{array}{l}\text { Higher vocational education, first } \\
\text { cycle professional education }\end{array}$ & First or second cycle academic education & -3.38 & 725 & 0.007 \\
\hline
\end{tabular}

U - Mann-Whitney U test; statistically significant differences were those with p-value lower than 0.017 (Bonferroni correction)

Table 6 Differences in WAI by type of shift

\begin{tabular}{llccc}
\hline Shift type & & $\begin{array}{c}\text { Mean } \\
\text { difference }\end{array}$ & $\mathbf{U}$ & $\mathbf{p}$ \\
\hline \multirow{2}{*}{ Morning shift } & Two-shift rotation & 1.97 & 3959 & 0.012 \\
\cline { 2 - 6 } & Three-shift rotation & -0.41 & 11092 & 0.905 \\
\hline Two-shift rotation & Three-shift rotation & -2.38 & 7642 & 0.001 \\
\hline
\end{tabular}

$\overline{\mathrm{U}}$ - test statistic of Mann-Whitney U test; statistically significant differences were those with p-value lower than 0.017 (Bonferroni correction)

\section{Conflicts of interest}

None to declare.

\section{REFERENCES}

1. Prochnow A, Magnago TSBS, Urbanetto JS, Beck CLC, Lima SBS, Greco PBT. Work ability in nursing: relationship with psychological demands and control over the work. Rev Latino-
Am Enfermagem 2013;21:1298-305. doi: 10.1590/01041169.3072.2367

2. Letvak S, Ruhm C, Gupta S. Differences in health, productivity and quality of care in younger and older nurses. J Nurs Manag 2013;21:914-21. doi: 10.1111/jonm.12181

3. Tavakoli-Fard N, Mortazavi SA, Kuhpayehzadeh J, Nojomi M. Quality of life, work ability and other important indicators of women's occupational health. Int J Occup Med Environ Health 2016;29:77-84. doi: 10.13075/ijomeh.1896.00329 
4. van den Berg TIJ, Elders LAM, de Zwart BCH, Burdorf A The effects of work-related and individual factors on the work ability index: A systematic review. Occup Environ Med 2009;66:211-20. doi: 10.1136/oem.2008.039883

5. Carel RS, Zusman M, Karakis I. Work ability index in Israeli hospital nurses: applicability of the adapted questionnaire. Exp Aging Res 2013;39:579-90. do i : 10.1080/0361073X.2013.839316

6. Tuomi K, Ilmarinen J, Jahkola A, Katajarinne L, Tulkki A. Work Ability Index. $2^{\text {nd }}$ revised ed. Helsinki: Finnish Institute of Occupational Health; 1998.

7. Ilmarinen J. Promoting active ageing in the workplace. European Agency for Safety and Health at Work 2012 [displayed 3 Apr 2019]. Available at https://osha.europa.eu/ en/publications/articles/promoting-active-ageing-in-theworkplace

8. Tuomi K, Ilmarinen J, Jahkola A, Katajarinne L, Tulkki A Indeks delovne zmožnosti [Work ability index, in Slovene]. Ljubljana: Inštitut Republike Slovenije za rehabilitacijo; 2005.

9. Dietner S. Indeks delovne zmožnosti invalidov zaposlenih v štirih invalidskih podjetjih Republike Slovenije: Specialistična naloga [Work ability index of disabled workers in four Slovenian companies for the disabled, in Slovene]. Ljubljana: Univerza v Ljubljani, Medicinska fakulteta, Katedra za javno zdravje; 2006.

10. Fatur-Videtič A, Dietner S. Indeks delovne zmožnosti: nove možnosti na področju ohranjanja in izboljševanja delovne zmožnosti [Work ability index: New opportunities for conserving and improving working capacity, in Slovene]. Delo in varnost 2005;50:25-6.

11. Fatur-Videtič A, Dietner S. Indeks delovne zmožnosti invalidov, zaposlenih v štirih invalidskih podjetjih v Republiki Sloveniji [Work capacity index of disabled persons employed in four enterprises in the Republic of Slovenia, in Slovene]. KIMDPŠ 2006;1(2):31-4.

12. Uršič C, Fatur-Videtič A. Razvijanje zaposljivosti in zaposlitvenih možnosti invalidov [Developing the employability and employment prospects for the disabled, in Slovene]. Delo in varnost 2006;51:57-9.

13. Škerjanc A, Dodič Fikfak M. Sickness presence among disabled workers at the University medical centre Ljubljana. Zdrav Var 2014;53:277-82. doi: 10.2478/sjph-2014-0030

14. Alavinia SM, van den Berg TIJ, van Duivenbooden C, Elders LAM, Burdorf A. Impact of work-related factors, lifestyle, and work ability on sickness absence among Dutch construction workers. Scand J Work Environ Health 2009;35:325-33. doi: 10.5271/sjweh.1340

15. Reeuwijk KG, Robroek SJW, Niessen MAJ, Kraaijenhagen RA, Vergouwe Y, BurdorfA. The prognostic value of the work ability index for sickness absence among office workers. PLoS One 2015;10(5):e0126969:1-13. doi: 10.1371/journal. pone.0126969

16. Schouten LS, Bültmann U, Heymans MW, Joling CI, Twisk JWR, Roelen CAM. Shortened version of the work ability index to identify workers at risk of long-term sickness absence. Eur J Public Health 2015;26:301-5. doi: 10.1093/eurpub/ ckv198

17. Mohammadi S, Ghaffari M, Abdi A, Bahadori B, Mirzamohammadi E, Attarchi M. Interaction of lifestyle and work ability index in blue collar workers. Glob J Health Sci 2015;7:90-7. doi: 10.5539/gjhs.v7n3p90
18. Arvidson E, Börjesson $\mathrm{M}$, Ahlborg G Jr, Lindegård A, Jonsdottir IH. The level of leisure time physical activity is associated with work ability-a cross sectional and prospective study of health care workers. BMC Public Health 2013;13:855. doi: 10.1186/1471-2458-13-855

19. Rutanen R, Luoto R, Raitanen J, Mansikkamäki K, Tomás E, Nygård CH. Short- and long-term effects of a physical exercise intervention on work ability and work strain in symptomatic menopausal women. Saf Health Work 2014;5:186-90. doi: 10.1016/j.shaw.2014.08.003

20. Jakobsen MD, Sundstrup E, Brandt M, Jay K, Aagaard P, Andersen LL. Physical exercise at the workplace prevents deterioration of work ability among healthcare workers: cluster randomized controlled trial. BMC Public Health 2015;15:1174. doi: 10.1186/s12889-015-2448-0

21. Milosevic M, Golubic R, Knezevic B, Golubic K, Bubas M, Mustajbegovic J. Work ability as a major determinant of clinical nurses' quality of life. J Clin Nurs 2011;20:2931-8. doi: 10.1111/j.1365-2702.2011.03703.x

22. Sorić M, Golubić R, Milošević M, Juras K, Mustajbegović J. Shift work, quality of life and work ability among Croatian hospital nurses. Coll Antropol 2013;37:379-84. PMID: 23940978

23. Padula RS, Comper MLC, Moraes SA, Sabbagh C, Pagliato Junior, W, Perracini MR. The work ability index and functional capacity among older workers. Braz J Phys Ther 2013; 17:38291. doi: 10.1590/S1413-35552012005000107

24. Čeledová L, Babková K, Rogalewicz V, Čevela R. The Work Ability Index for persons aged $50+$ as an instrument for implementing the concept of Age Management. Kontakt 2014;16:e242-8. doi: 10.1016/j.kontakt.2014.10.003

25. Converso D, Sottimano I, Guidetti G, Loera B, Cortini M, Viotti S. Aging and work ability: the moderating role of job and personal resources. Front Psychol 2018;8:2262. doi: 10.3389/fpsyg.2017.02262

26. Müller A, Weigl M, Heiden B, Glaser J, Angerer P. Promoting work ability and well-being in hospital nursing: the interplay of age, job control, and successful ageing strategies. Work 2012;41(Suppl 1):5137-44. doi: 10.3233/WOR-2012-0083-5137

27. Golubic R, Milosevic M, Knezevic B, Mustajbegovic J. Workrelated stress, education and work ability among hospital nurses. J Adv Nurs 2009;65:2056-66. doi: 10.1111/j.1365-2648.2009.05057.x

28. Knezevic B, Milan M, Golubic R, Belosevic L, Russo A, Mustajbegovic J. Work-related stress and work ability among Croatian university hospital midwives. Midwifery 2011;27:146-53. doi: 10.1016/j.midw.2009.04.002

29. Li H, Liu Z, Liu R, Li L, Lin A. The relationship between work stress and work ability among power supply workers in Guangdong, China: a cross-sectional study. BMC Public Health 2016;16:123. doi: 10.1186/s12889-016-2800-z

30. Bethge M, Radoschewski FM, Müller-Fahrnow W. Work stress and work ability: cross-sectional findings from the German sociomedical panel of employees. Disabil Rehabil 2009;31:692-9. doi: 10.1080/09638280902751949

31. Kordi M, Mohamadirizi S, Shakeri MT, Modares Gharavi M, Salehi Fadardi J. Relationship between occupational stress and work ability of midwives in Mashhad, Iran. J Midwifery Reprod Health 2014;2:188-94.

32. Monteiro MS, Costa Alexandre NM, Ilmarinen J, Mendes Rodrigues C. Work ability and musculoskeletal disorders 
among workers from a public health institution. Int J Occup Saf Ergon 2009;15:319-24. doi: $10.1080 / 10803548.2009 .11076813$

33. Bugajska J, Sagan A. Chronic musculoskeletal disorders as risk factors for reduced work ability in younger and ageing workers. Int J Occup Saf Ergon 2014;20:607-15. doi: 10.1080/10803548.2014.11077069

34. Magnago TSBS, de Lima ACS, Prochnow A, Ceron MDS, Tavares JP, Urbanetto, JS. Intensity of musculoskeletal pain and (in) ability to work in nursing. Rev Latino-Am Enfermagem 2012;20:1125-33. doi: 10.1590/S010411692012000600015

35. Bethge M, Borngräber Y. Work-family conflicts and selfreported work ability: cross-sectional findings in women with chronic musculoskeletal disorders. BMC Musculoskelet Disord 2015;16:58. doi: 10.1186/s12891-015-0515-4

36. Derycke H, Clays E, Vlerick P, D'Hoore W, Hasselhorn HM, Braeckman L. Perceived work ability and turnover intentions: a prospective study among Belgian healthcare workers. J Adv Nurs 2012;68:1556-66. doi: 10.1111/j.1365-2648.2012.05961.x

37. Camerino D, Conway PM, Van der Heijden BI, Estryn-Behar M, Consonni D, Gould D, Hasselhorn HM. Low-perceived work ability, ageing and intention to leave nursing: a comparison among 10 European countries. J Adv Nurs 2006;56:542-52. doi: 10.1111/j.1365-2648.2006.04046.x

38. Rongen A, Robroek SJW, van der Heijden BIJM, Schouteten R, Hasselhorn HM, Burdorf A. Influence of work-related characteristics and work ability on changing employer or leaving the profession among nursing staff. J Nurs Manag 2014;22:1065-75. doi: 10.1111/jonm.12066

39. Rotenberg L, Griep RH, Fischer FM, Fonseca Mde J, Landsbergis P. Working at night and work ability among nursing personnel: when precarious employment makes the difference. Int Arch Occup Environ Health 2009;82:877-85. doi: 10.1007/s00420-008-0383-4

40. da Silva FJ, Felli VE, Martinez MC, Mininel VA, Ratier AP. Association between work ability and fatigue in Brazilian nursing workers. Work 2016;53:225-32. doi: 10.3233/WOR152241

41. Roelen CAM, van Rhenen W, Groothoff JW, van der Klink JJ, Twisk JWR, Heymans MW. Work ability as prognostic risk marker of disability pension: single-item work ability score versus multi-item work ability index. Scand J Work Environ Health 2014;40:428-31. doi: 10.5271/sjweh.3428

42. El Fassi M, Bocquet V, Majery N, Lair ML, Couffignal S, Mairiaux P. Work ability assessment in a worker population: comparison and determinants of Work Ability Index and Work Ability score. BMC Public Health 2013;13:305. doi: 10.1186/1471-2458-13-305

43. Mokarami H, Mortazavi SB, Asgari A, Choobineh A. Work Ability Score (WAS) as a suitable instrument to assess work ability among Iranian workers. Health Scope 2017;6:e42014. doi: $10.17795 /$ jhealthscope-42014

44. Geukes M, van Aalst MP, Nauta MC, Oosterhof, H. The impact of menopausal symptoms on work ability. Menopause 2012;19:278-82. doi: 10.1097/gme.0b013e31822ddc97

45. Han L, Shi L, Lu L, Ling L. Work ability of Chinese migrant workers: the influence of migration characteristics. BMC Public Health 2014;14:353. doi: 10.1186/1471-2458-14-353

46. Lian Y, Xiao J, Zhang C, Guan S, Li F, Ge H, Liu J. A comparison of the relationships between psychosocial factors, occupational strain, and work ability among 4 ethnic teacher groups in China. Arch Environ Occup Health 2016;71:74-84. doi: org/10.1080/19338244.2014.956859

47. Habibi E, Dehghan H, Zeinodini M, Yousefi H, Hasanzadeh A. A study on work ability index and physical work capacity on the base of fax equation VO2 max in male nursing hospital staff in Isfahan, Iran. Int J Prev Med 2012;3:776-82. PMCID PMC3506089

48. Ghaddar A, Ronda E, Nolasco A. Work ability, psychosocial hazards and work experience in prison environments. Occup Med (Lond) 2011;61:503-8. doi: 10.1093/occmed/kqr124

49. Müller A, Weigl M, Heiden B, Herbig B, Glaser J, Angerer P. Selection, optimization, and compensation in nursing: exploration of job-specific strategies, scale development, and age-specific associations to work ability. J Adv Nurs 2013;69:1630-42. doi: 10.1111/jan.12026

50. Müller A, Heiden B, Herbig B, Poppe F, Angerer P. Improving well-being at work: a randomized controlled intervention based on selection, optimization, and compensation. J Occup Health Psychol 2016;21:169-81. doi: 10.1037/a0039676

51. von Bonsdorff ME, von Bonsdorff MB, Zhou ZE, Kauppinen M, Miettinen M, Rantanen T, Vanhala S. Organizational justice, selection, optimization with compensation, and nurses' work ability. J Occup Environ Med 2014;56:326-30. doi: 10.1097/ JOM.0000000000000102

52. Fischer FM, Martinez MC. Individual features, working conditions and work injuries are associated with work ability among nursing professionals. Work 2013;45:509-17. doi: 10.3233/WOR-131637

53. Monteiro I, Chillida Mde S, Moreno LC. Work ability among nursing personnel in public hospitals and health centers in Campinas - Brazil. Work 2012;41(Suppl 1):316-9. doi: 10.3233/WOR-2012-0176-316

54. Rostamabadi A, Zamanian Z, Sedaghat Z. Factors associated with work ability index (WAI) among intensive care units' (ICUs') nurses. J Occup Health 2017;59:147-55. doi: 10.1539/ joh.16-0060-OA

55. WAI-Netzwerk Deutschland. WAI-Fragebogen \& Auswertung (Kurzversion) [displayed 18 Feb 2018]. Available at http:// www.arbeitsfaehig.com/uploads/z-neue\%20Uploads/WAINetzwerk/WAI-Fragebogen-Kurzversion $\% 20$ mit $\% 20$ Auswertungsbogen.pdf

56. WAI-Netzwerk Deutschland. WAI-Fragebogen (Berechnungsmethode) [displayed $18 \mathrm{Feb} 2018$ ]. Available at http://wai-netzwerk.uni-wuppertal.de/picture/upload/file/WAIBerechnungsmethode_2015.pdf

57. Thinschmidt M, Seibt R. "Work Ability-Index" - Vergleich von Lang- und Kurzversion der Krankheitsdiagnosen anhand einer deutschen Stichprobe ["Work ability index" - Comparison of the long and short version of illness diagnoses by means of a German random sample, in German]. Zbl Arbeitsmed 2007;57:212-21. doi: 10.1007/BF03349124

58. Nowrouzi B, Lightfoot N, Carter L, Larivère M, Rukholm E, Belanger-Gardner D. Workplace system factors of obstetric nurses in Northeastern Ontario, Canada: Using a work disability prevention approach. Saf Health Work 2015;6:30511. doi: 10.1016/j.shaw.2015.07.004

59. The collective agreement for employees in health care [displayed 24 Nov 2019]. Available at http://www.pisrs.si/Pis. web/pregledPredpisa?id=KOLP52 


\section{Indeks delovne zmožnosti medicinskih sester starih 50 let in več v hospitalni dejavnosti v Sloveniji}

Izvajalci zdravstvene nege z zmanjšano delovno zmožnostjo so bolj dovzetni za negativne vplive delovnega okolja ter podvrženi tveganju za bolniško odsotnost, invalidnost in predčasno upokojevanje. Namen raziskave je oceniti delovno zmožnost izvajalcev zdravstvene nege starih 50 let in več, zaposlenih v hospitalni dejavnosti v Sloveniji, s ciljem raziskati povezavo med oceno delovne zmožnosti in trenutno delovno zmožnostjo ter demografskimi dejavniki. V raziskavi, ki je potekala od aprila do decembra 2016 je sodelovalo 433 izvajalcev zdravstvene nege 50 let in več, iz 13 bolnišnic na sekundarnem nivoju v Sloveniji. Uporabljen je standardiziran merski instrument za merjenje delovne zmožnosti (WAI), kratke verzije. Izračunana aritmetična srednja vrednost WAI je znašala 36,98 $\pm 6,46$ ter mediana 38 . Ob predpostavki $\mathrm{p}=0.05$ je bilo ugotovljeno, da starost in WAI nista povezani $(\rho=-0.034, \mathrm{p}=0.475)$. Izkazalo se je, da sta oceni WAI in »trenutna delovna zmožnost « močno pozitivno povezani $(\rho=0,726, p<0.001)$. Demografske spremenljivke kot so višja izobrazba, polni delovni čas, enoizmenski ali triizmenski turnus so v naši raziskavi povezane z višjo oceno WAI. Izračunani WAI pri medicinskih sestrah, starejših od petdeset let, kaže na potrebo po sistemskih spremembah v okolju zdravstvene nege, tako da da bodo zaposleni v zdravstveni negi lahko ohranjali dobro delovno sposobnost vse do upokojitvene starosti in dlje.

KLJUČNE BESEDE: delovno mesto; demografski dejavniki; zdravstvena nega 